\title{
CFD simulation and measurement of the thermal behavior inside a room of the institutional library: a comparative study
}

\author{
Simulação CFD e medição do comportamento térmico no \\ interior de uma sala da biblioteca institucional: um \\ estudo comparativo
}

\section{Efrén Vázquez Silva \\ Franco David Cajas Muñoz \\ Marcelo Xavier Asitimbay Deleg \\ Paúl Bolívar Torres J ara \\ Gabriela Abad Farfán}

${ }^{1}$ Efrén Vázquez Silva ${ }^{1}$ Universidade Politécnica Salesiana Cuenca - Ecuador

\footnotetext{
${ }^{2}$ Franco David Cajas Muñoz ${ }^{2}$ Universidade Politécnica Salesiana Cuenca - Ecuador
}

${ }^{3}$ Marcelo Xavier Asitimbay

Deleg

${ }^{3}$ Universidade Politécnica Salesiana Cuenca - Ecuador

${ }^{4}$ Paúl Bolívar Torres J ara 4Universidade Politécnica Salesiana Cuenca - Ecuador

${ }^{5}$ Gabriela Abad Farfán 5Universidade Politécnica Salesiana Cuenca - Ecuador

Recebido em 02/08/18 Aceito em 12/12/18

\section{Abstract<smiles>[TlH]</smiles>

his article presents the results of the comparison between the CFD simulation and temperature measurements, both in the time domain, at a certain point of interest within a specific closed space (cubicle) of the institutional library of the Salesian Polytechnic University (UPS), at its headquarters in the city of Cuenca, Republic of Ecuador. In this specific case, solar radiation is considered as the main heat transfer mechanism, which is why it was considered in the applied simulation method. An acceptable relative error was obtained between the simulated and measured temperature values. During the summer period, the thermal conditions inside the cubicle are not suitable for the comfort of the users. The study developed can constitute a basic tool for possible future research related to the implementation of climate conditioning for the cubicle, the library in general and any other site with similar constructive and operational characteristics.

Keywords: Solar radiation. Heat transfer. CFD.

\section{Resumo}

Esse artigo apresenta os resultados da comparação entre a simulação CFD e as medições de temperatura, ambas no domínio do tempo, em um determinado ponto de interesse dentro de um espaço fechado específico (cubículo) da biblioteca institucional da Universidade Politécnica Salesiana (UPS), na sua sede na cidade de Cuenca, República do Equador. Neste caso, a radiação solar é considerada como o principal mecanismo de transferência de calor, razão pela qual este mecanismo é considerado no método de simulação aplicado. Um erro relativo aceitável foi obtido entre os valores de temperatura simulados e medidos. Durante o período de verão, as condições térmicas dentro do cubículo não são adequadas para o conforto dos usuários. O estudo desenvolvido pode constituir uma ferramenta básica para possíveis pesquisas futuras relacionadas à implementação do condicionamento climático para o cubículo, a biblioteca em geral e qualquer outro local com semelhantes características construtivas e operacionais.

Palavras-chave: Radiação solar. Transferência de calor. CFD. 


\section{Introduction}

Heat gains or losses in closed spaces are through opaque and semi-transparent materials: roofs, walls, skylights and windows. Semi-transparent materials are responsible for a larger amount of unwanted heat gains and losses, representing a high risk of thermal discomfort Gijón-Rivera et al., (2013). The improvement of living and working conditions of human beings has been a constant concern of researchers throughout the history of society. In recent stages we can see this problem reflected in works such as, for example, that of González-Cruz and González-García (2013), where passive cooling systems of the roofs of certain enclosures are studied, through the application of roof-pond metallic typology. Ordóñez and Pérez (2015) make a comparison related to energy savings, between green and white roofs in a construction with a joist presented system with concrete and vault. Also, in Muñoz et al. (2015), the authors foresee the optimal use of natural ventilation according to the location and orientation of a building.

Another line of work in this regard has been the development of research in which numerical techniques are applied. In this case we can point out the works of Esteban et al. (2015, 2016). In Esteban et al. (2015) the transient phenomenon of natural convection is numerically analyzed in a trapezoidal enclosure. The authors characterize the aspect ratios: quotient between height and length of the enclosure and the angle of inclination of the walls of this space, which depends on the so-called aspect ratio. Whereas in Esteban et al. (2016) the same authors address this problem, for the same type of enclosure; however, in this case the active walls (lower and upper) are symmetrically inclined.

Within the same line of research other studies were conducted, for example, Gowreesunker and Tassou (2013), Barbason and Reiter (2014) and GijónRivera et al. (2013). In Gowreesunker and Tassou (2013) a validation study of Computational Fluid Dynamics (CFD) models used to predict the effect of phase change material-clay boards on the control of indoor environments, in ventilated and nonventilated situations is reported. On the other hand, in Barbason and Reiter, (2014) the authors report the coupling of a building energy simulation (BES) made with the commercial software package developed at the University of Wisconsin (TRNSYS) with a CFD simulation made with ANSYS FLUENT, and its application to a typical Belgian two-storey house. Whereas in Gijón-Rivera et al. (2013) the advantages of using a BES-CFD instead individual solutions are shown; and the results are applied to a room on top of a building with three different glazed configurations in Mexico City.

The study of the thermal behavior of habitable space of buildings of different types also developed. In the case of the use of adobe as a construction material, Cárdenas (2015) can be mentioned. Another way to evaluate this thermal behavior is the simultaneous collection, indoors and outdoors, of temperature and relative humidity data, in order to propose bioclimatic design strategies (see Rodríguez and Peñaranda (2015)). In Muñoz et al. (2014) the authors proceeded in a similar way, as they analyzed continuous and systematic measurements of temperature and humidity at specific points in the interior of a building, and external meteorological variables. This information was correlated to an analytical model that explained the contributions of conductivity, radiation and convection due to the wind in the consideration of the thermal properties of the building. In Varini (2015), Varini studied a constructive model of family housing and simulated its behavior in terms of ventilation flows, temperature and relative humidity inside, under various conditions, all focused on issuing conclusions on the thermal comfort of the tenants.

Finally, we refer to Felices and collaborators, who in Felices et al. (2017) reflected the study of the thermal performance of a solar space adhered to a bioclimatic building. In this case, the effect of direct solar radiation and the absorption of opaque building systems and the thermal properties of the air enclosed in the solar space was analyzed through the comparison of experimental and numerical data to predict thermal performance.

In the present work, only the variation of the temperature in a certain enclosure within the university library was simulated, and the comparison with measurements experimentally taken in the same space was made. The library of the Salesian Polytechnic University, in Cuenca, within its facilities has 8 cubicles designated to work in groups (see Figure 1), so that the study conditions of other users are not affected. Another aspect that impacts the activity of students in this space is thermal comfort. In this sense, there was a need to evaluate the thermal behavior inside the cubicle. 
Figure 1 - UPS library building

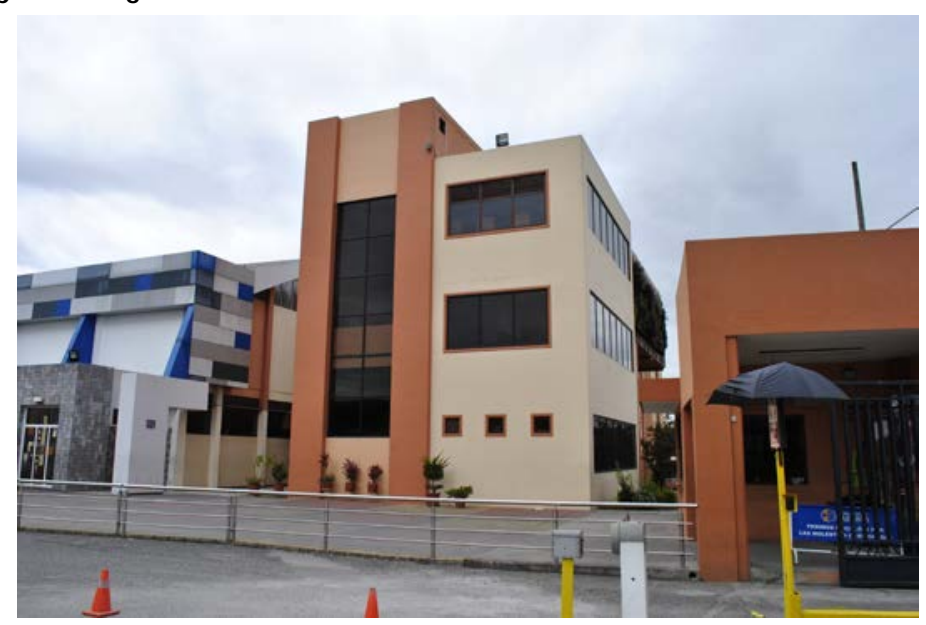

Figure 2 - Position of the cubicle inside the structure

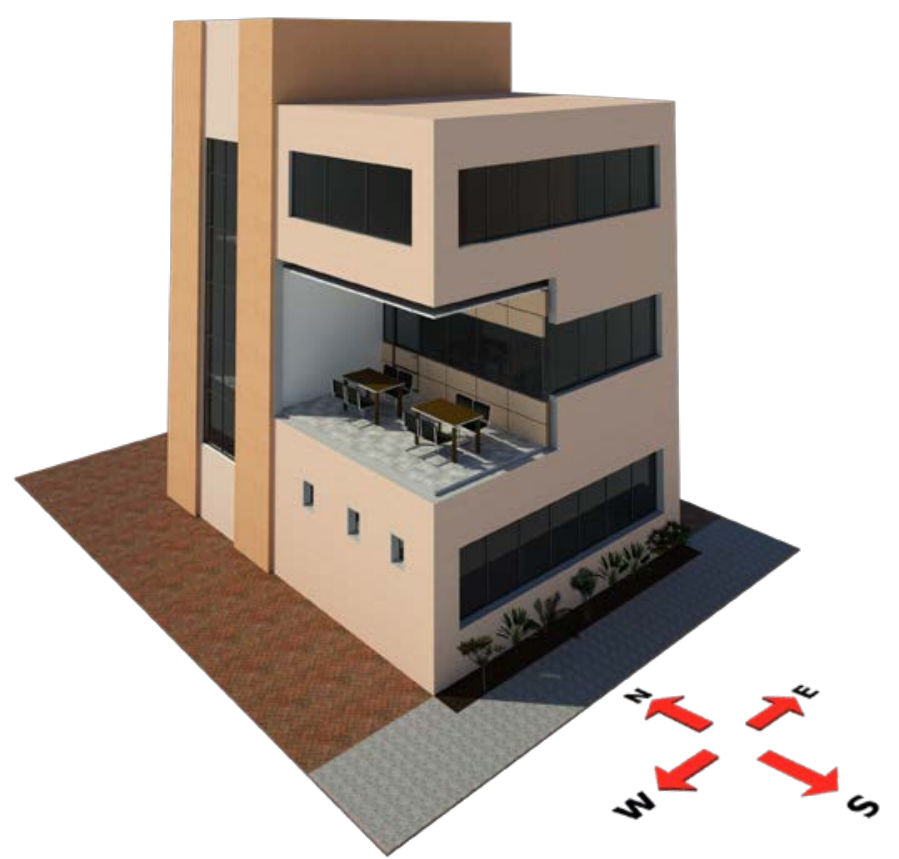

Figure 2 shows the modeling of the building in which the library is located, where it is possible to view the location of the reference cubicle.

One of the factors that affects such behavior, and that manifests with greater force in the considered space, is the heating caused by solar radiation and natural convection. Thus, we proposed in this study to simulate the thermal behavior in a certain area of interest in the enclosure, in which its occupants perceive the greatest influence of heat, considering only the action of the solar rays during a critical interval of the day, in the absence of people. Simulation that, enriched with other parameters (that is, for example, factors related to human comfort and others, reported, for example, in
Instituto Ecuatoriano de Normalización (2019), Çengel and Ghajar (2011), Çengel and Boles (2003), Decrofet (2019) and Fernández (1994)), could be used as an additional criterion for the design of an appropriate climate conditioning system for enclosures with similar conditions to those considered.

The work is organized as followed: The applied methodology is exposed in the next section. Afterwards, following sections address the physical situation and the analysis of results obtained with a CFD simulation. The conclusions about the developed study, and recommendations for possible future investigations are offered at the end of the study. 


\section{Methodology}

The temperature in the center of the cubicle was measured during a certain time interval, with an electronic sensor, which together with a microprocessor and software, allowed to store and interpret the obtained data. Then, these results were compared with the temperature variation curve obtained with the help of the simulation developed in the FLUENT module of the ANSYS software (software used because UPS acquired its license). Temperature data were also collected on the surfaces that delimit the enclosure, to determine the boundary conditions (input data for the software) that would later be used in the simulation. This methodology is described through its different phases:

\section{Data collection}

Initially the dimensions of the cubicle were measured and the recognition of the type of constituent materials of the elements or structures that delimit the enclosure was made (Table 2) (AMERICAN..., 2013). Then, during several days, temperature measurements were taken inside the space and throughout the day. This allowed to establish the time interval during which the temperature inside reached maximum values $(15: 00$ to $17: 00$ hours). For this reason, both the simulation and the temperature measurements were performed synchronously, with an increase in time of 240s and setting as initial time at 15:00 hours. The temperature values were acquired through a LM35 sensor, which is part of an ARDUINO-MATLAB interface, located at the point of interest. This way, it was possible to obtain a database with temperature values for each instant of time at one second intervals.

\section{Simulation}

As input conditions for the software, some thermal properties (emissivity, thermal conductivity, specific heat and absorptivity), the density and the filtering capacity of the solar rays of the different materials described in the previous phase, were considered. In addition, the coefficient of heat transfer (or thermal transmittance) for each type of material was calculated. Also, data of the average temperature on each boundary surface of the cubicle were collected with the help of thermography camera brand TESTO, model 875, with manual entry of the value of the emissivity coefficient of each type of material. All this information constituted the input data (see Tables 1, 2 and 3) (AMERICAN..., 2013). That is, the set of boundary conditions for the mathematical model of the simulation was conformed for each type of constituent material of the limiting surfaces of the cubicle, by the thermal properties of each material; the temperature of each surface at the initial instant, taken with the camera TESTO; and the ambient temperature inside the enclosure at the initial instant.

Table 1 - Thermal properties of materials

\begin{tabular}{l|c|c|c}
\hline \multicolumn{1}{c|}{ Material } & Density $\left(\mathbf{k g} / \mathbf{m}^{3}\right)$ & $\begin{array}{c}\text { Specific Heat } \\
(\mathbf{J} / \mathbf{K G ~ k )}\end{array}$ & $\begin{array}{c}\text { Thermal Conductivity } \\
\mathbf{( w / m ~ k )}\end{array}$ \\
\hline Glass & 2470 & 750 & 1.0 \\
Wood & 750 & 2390 & 0.176 \\
Concrete (Floor) & 2300 & 653 & 0.93 \\
Concrete (Walls) & 1970 & 800 & 0.7 \\
Gypsum & 1200 & 1080 & 0.43 \\
Air & 1.196 & 1007 & 0.0252 \\
\hline
\end{tabular}

Table 2 -Thermal conditions

\begin{tabular}{l|l|l|c|c|c|c}
\hline Zone & $\begin{array}{c}\text { Thermal } \\
\text { conditions }\end{array}$ & Material name & $\begin{array}{c}\text { Heat transfer } \\
\text { coefficient } \\
\left(\mathbf{w} / \mathbf{m}^{2} \mathbf{- k}\right)\end{array}$ & $\begin{array}{c}\text { Free stream } \\
\text { temperature } \\
\left({ }^{\circ} \mathbf{C}\right)\end{array}$ & $\begin{array}{c}\text { Internal } \\
\text { emissivity }\end{array}$ & $\begin{array}{c}\text { Wall thickness } \\
(\mathbf{m})\end{array}$ \\
\hline Roof & convection & Gypsum panel & 2.33 & 23.7 & 0,90 & 0,1 \\
Floor & convection & Concrete & 1.64 & 23.7 & 0,85 & 0,25 \\
Walls & convection & Hollow block & 2.63 & 23.7 & 0,85 & 0,15 \\
Door & convection & Wood panel & 1.39 & 23.7 & 0,90 & 0,08 \\
Glass & convection & Glass & 5.56 & 23.7 & 0,94 & 0,01 \\
\hline
\end{tabular}


Table 3 -Radiation conditions

\begin{tabular}{l|c|c|c|c|c|c}
\hline Zone & $\begin{array}{c}\text { Boundary } \\
\text { condition type }\end{array}$ & $\begin{array}{c}\text { Participates } \\
\text { in solar ray } \\
\text { tracing }\end{array}$ & $\begin{array}{c}\text { Absorptivity } \\
\text { direct } \\
\text { visible }\end{array}$ & $\begin{array}{c}\text { Absorptivity } \\
\text { direct } \\
\text { infrared rays }\end{array}$ & $\begin{array}{c}\text { Transmissivity } \\
\text { direct visible }\end{array}$ & $\begin{array}{c}\text { Transmissivity } \\
\text { direct } \\
\text { infrared rays }\end{array}$ \\
\hline Roof & opaque & no & - & - & - & - \\
Floor & opaque & yes & 0,65 & 0,65 & - & - \\
Walls & opaque & yes & 0,65 & 0,65 & - & - \\
Door & opaque & yes & 0,59 & 0,59 & - & - \\
Glass & semi-transparent & yes & 0,15 & 0,15 & 0,88 & 0,88 \\
\hline
\end{tabular}

The heat transfer coefficient (Table 2) (AMERICAN..., 2013) is a property of the materials that depends on the wall thickness and the thermal conductivity, the values presented were calculated by the authors. The ambient temperature inside the cubicle is the arithmetic mean of the different temperatures at which the cubicle air was at 15:00 hours (start of the analysis) during 10 days in which the measurements were made. Finally, the internal emissivity values were taken from ASHRAE (AMERICAN..., 2013).

The false ceiling does not participate in solar radiation because there is another level above the enclosure and the solar rays have no incidence on the ceiling; it only participates in convection. In addition, the respective values were taken from ASHRAE (AMERICAN..., 2013).

Subsequently, the three-dimensional model of the enclosure under study was obtained and its orientation towards the sun was taken into account (Figure 3). For the runs of the simulation, the software calculated the relative initial position of the sun with respect to the cubicle and its trajectory from that moment; and for this it was necessary to enter, also as input data, the date, the time of day, the time zone and the geographic coordinates of the building. Because of these software facilities, it was possible to perform the synchronous analysis, that is, the times of increase and duration of the measurements and of the simulation were equal.

Finally, the simulation of the combined action of the different thermal transfer mechanisms from the limiting surfaces towards the interior of the room was carried out. The mathematical model on which the FLUENT module was supported can be consulted, for example, in Gowreesunker and Tassou (2013):

$\frac{\partial \rho}{\partial t}+\frac{\partial}{\partial x_{j}}\left(\rho u_{j}\right)=S_{M}$

$\frac{\partial}{\partial t}(\rho H)=-\frac{\partial}{\partial x_{j}}\left(\rho u_{j} C_{p} T\right)+\frac{\partial}{\partial x_{j}}\left(\lambda \frac{\partial T}{\partial x_{j}}\right)+S_{E}$ Eq. 2

$\partial / \partial t\left(\rho u_{-} j\right)+\partial /\left(\partial x_{-} j\right)\left(\rho u_{-} i u_{-} j\right)=-\partial /$

$\left(\partial x_{-} j\right)(P)+\partial /\left(\partial x_{-} j\right)\left(\tau^{-}\right)+\rho g_{-} j+F_{-} j$ Eq. 3
Equations 1, 2 and 3 are continuity equation, energy equation and momentum equation respectively; in which: $\rho$ : density; $x_{j}$ : direction vector; $u_{j}, u_{i}$ : velocity vectors; $S_{M}$ : mass source term; $H$ : enthalpy; $C_{p}$ : specific heat capacity; $T$ : temperature; $\lambda$ : thermal conductivity; $S_{E}$ : energy source term; $P$ : static pressure; $\bar{\tau}$ : stress tensor; $g_{j}$ : gravitational force vector; $F_{j}$ : body force vector.

The FLUENT module of the ANSYS implemented second-order explicit methods for the discretization of the transient terms of the equations of momentum and energy; as well as for the advective and diffusive terms.

\section{Reading of the analytical outputs, and graphic}

The used software allowed to obtaining the curves of temperature versus time in any surface or point of the cubicle, and images of the temperature distribution on walls and on any fictitious planes inside the enclosure.

\section{Physical situation}

For the computational simulation, only the cubicle was modeled, however, indirectly, the possible incidence of the neighboring rooms on the corresponding limiting surfaces of the place of interest was taken into account in the input data. The study area was characterized by the absence of air flows, because it generally remained closed. It had only the access door (possible way of air intake, however, this was not considered because when the room was being used, the door was kept closed due to institutional regulations) and did not have no any kind ventilation.

Simulation test runs were carried out assuming the mathematical model with and without turbulence, and the differences in the results were negligible. However, the turbulence model considerably increases the computation times. So, for this and the previous reason, for the simulation, a model of turbulence was not used. 


\section{Figure 3 - Three-dimensional model of the cubicle}

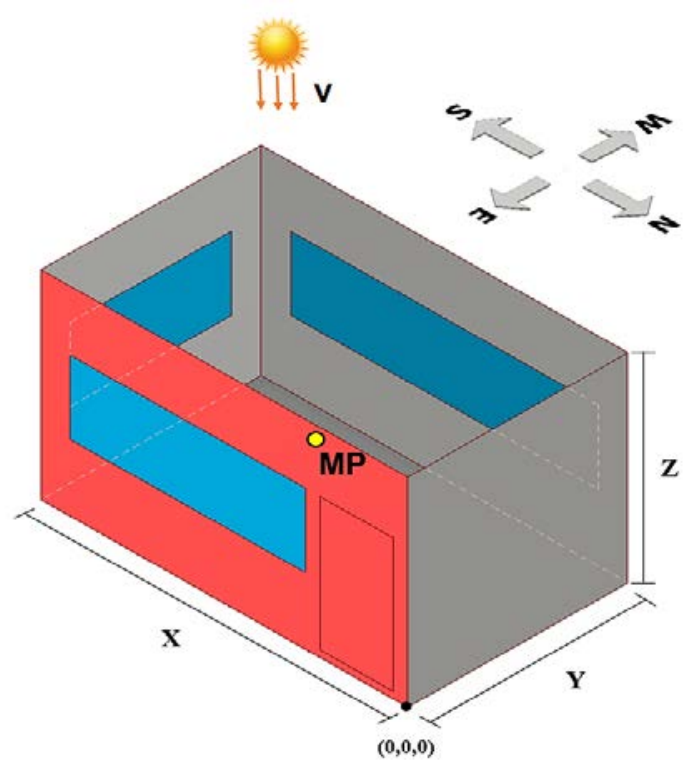

Nor was the incidence of relative humidity considered for the simulation because in the region of the country where the building was located, the average annual relative humidity remained within the human comfort zone (62\%) (PESÁNTES, 2012).

The coordinates of the measurement point in the cubicle, called MP, were (2.65 m, $1.45 \mathrm{~m}, 1.50 \mathrm{~m})$; considered from the origin $(0,0,0)$ as shown in Figure 1. In addition, the cubicle had the following dimensions:

$X=5.3 m$

$Y=2.9 m$

$Z=3.2 m$

In the same figure 1 the colors identify:

Blue = Glass;

Gray = Concrete walls; and

Red $=$ Wooden wall and door.

Also, the location of the Sun is specified as follows:

$\vec{V}:$ direction vector of the Sun

$\vec{V}=(-0.502,0.305,0.808)$

The cubicle was located in a corner of a two-story building, on the first floor; in such a way that two of its walls were in direct contact with the exterior, oriented towards the west and the south (see Figure 2).

\section{Results and discution}

The information collected in phase 1 , of the ambient temperature of the enclosure at the measurement point MP, was compared with the results of the computational simulation, obtained with three mesh resolutions: fine, medium and coarse. The data were obtained within the same time range (15:00 to 17:00 hours) and with the same time-step (240s), obtaining the following graph of temperature variation (see Figure 3).

Next, in Figure 4, it is possible to observe details of the different types of grids used for the simulation runs, and this offers a visual idea about the relationship between the size of the differential element and the dimensions of the cubicle (information provided by the software itself). Table 4 shows a summary of the characteristics of the grids (the values of skewness and orthogonal quality are averaged).

It can be seen, according to the distribution of points in the plane shown in Figure 5, that there was no considerable deviation between the two results; the stabilization time was approximately the same and also the maximum temperature was reached for the same value of $t$ in both cases.

Similarly, it can be seen that once the maximum temperature was reached, it was maintained until approximately $16: 20$ hours due to the thermal inertia in the room, and from that moment it began to decay due to the Earth's rotation effect.

To corroborate the results of the previous graph, below is a summary table (Table 5) that shows the relative errors between each temperature value measured over the time interval of interest and the corresponding simulated value, for each mesh resolution and also the total average error between simulated and measured results. 
Figure 4 - Details of the different types of meshing; hexahedral elements.

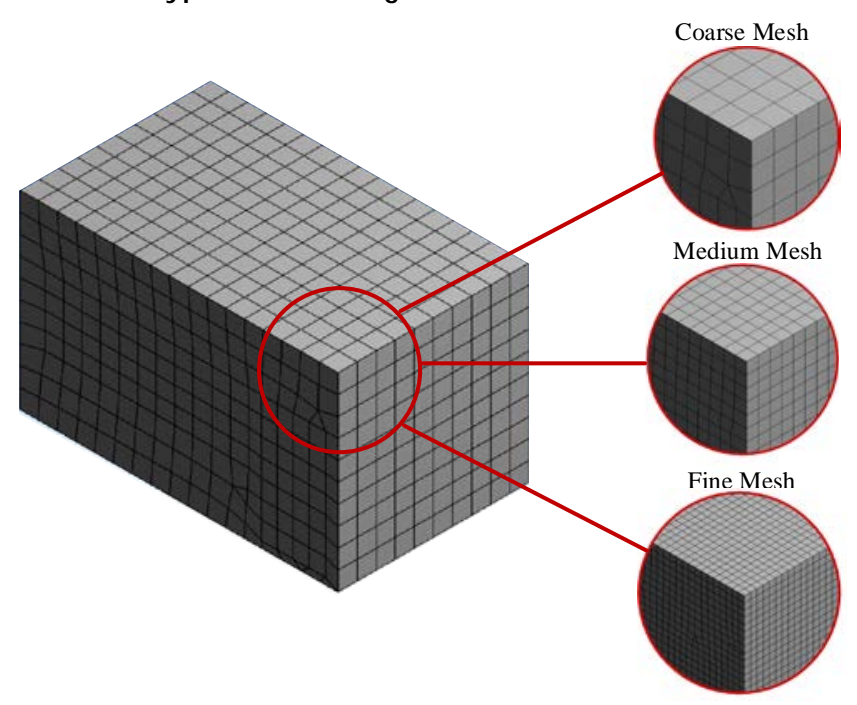

Table 4 - Summary of meshing characteristics

\begin{tabular}{l|c|c|c|c}
\hline \multicolumn{1}{c}{ Grid } & Number of elements & Number of nodes & Skewness & Orthogonal Quality \\
\hline Coarse & 2089 & 2260 & 0,204 & 0,880 \\
Medium & 14706 & 16172 & 0,068 & 0,971 \\
Fine & 116177 & 116055 & 0,101 & 0,942 \\
\hline
\end{tabular}

Figure 5 - Experimental and simulated results

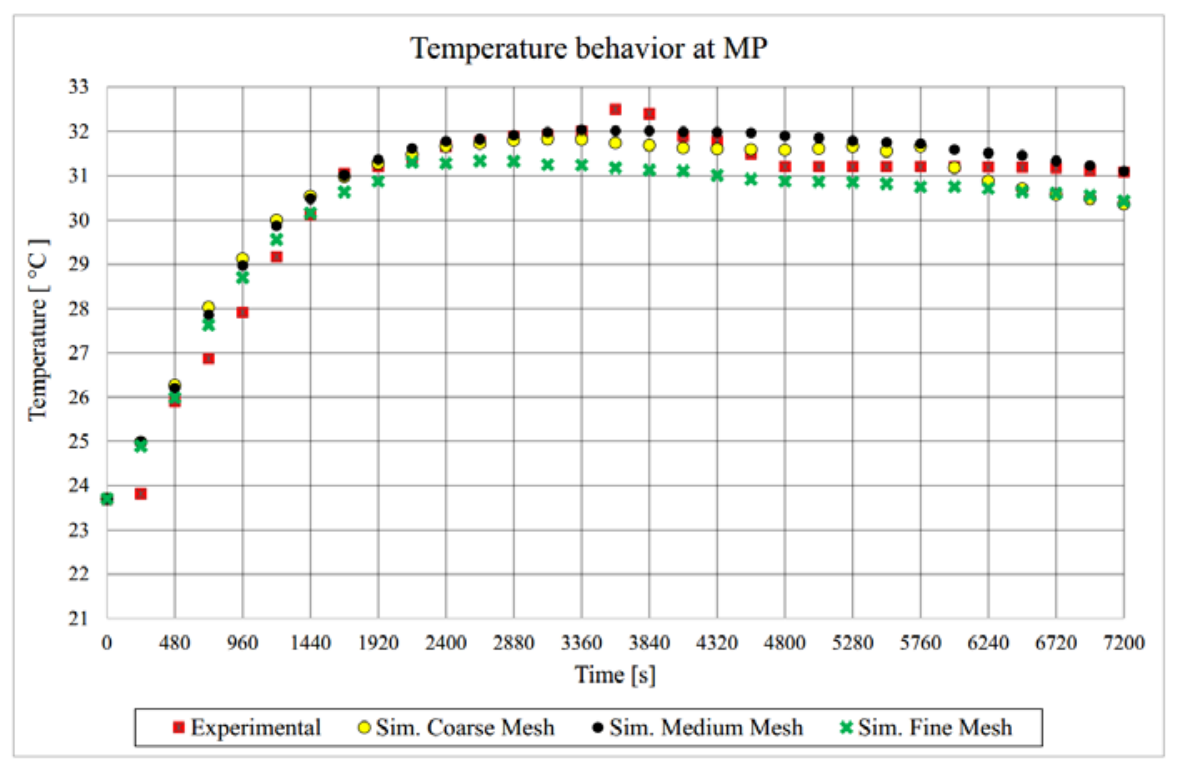


Table 5 - Summary of relative errors

\begin{tabular}{|c|c|c|c|c|c|c|c|}
\hline $\begin{array}{c}\text { Time } \\
\text { (s) }\end{array}$ & $\begin{array}{c}\text { Measured } \\
\text { temperature } \\
\left({ }^{\circ} \mathrm{C}\right)\end{array}$ & $\begin{array}{c}\begin{array}{c}\text { Simulated } \\
\text { temperature }\end{array} \\
\text { (fine mesh, } \\
\left.{ }^{\circ} \mathrm{C}\right)\end{array}$ & $\begin{array}{c}\text { Error } \\
(\%)\end{array}$ & $\begin{array}{c}\begin{array}{c}\text { Simulated } \\
\text { temperature } \\
\text { (medium mesh, } \\
{ }^{\circ} \mathrm{C} \text { ) }\end{array} \\
\end{array}$ & $\begin{array}{c}\text { Error } \\
(\%)\end{array}$ & $\begin{array}{c}\text { Simulated } \\
\text { temperature } \\
\left(\text { coarse mesh, }{ }^{\circ} \mathrm{C}\right)\end{array}$ & Error (\%) \\
\hline 1 & 23,691 & 23,700 & 0,038 & 23,700 & 0,038 & 23,700 & 0,038 \\
\hline 240 & 23,812 & 24,895 & 4,548 & 24,990 & 4,947 & 24,983 & 4,917 \\
\hline 480 & 25,900 & 25,981 & 0,313 & 26,200 & 1,158 & 26,261 & 1,394 \\
\hline 720 & 26,870 & 27,628 & 2,822 & 27,850 & 3,647 & 28,024 & 4,294 \\
\hline 960 & 27,910 & 28,697 & 2,820 & 28,970 & 3,798 & 29,124 & 4,351 \\
\hline 1200 & 29,170 & 29,558 & 1,329 & 29,870 & 2,400 & 29,995 & 2,829 \\
\hline 1440 & 30,120 & 30,157 & 0,123 & 30,480 & 1,195 & 30,537 & 1,384 \\
\hline 1680 & 31,050 & 30,629 & 1,355 & 31,000 & 0,161 & 30,980 & 0,226 \\
\hline 1920 & 31,200 & 30,872 & 1,051 & 31,360 & 0,513 & 31,277 & 0,248 \\
\hline 2160 & 31,400 & 31,305 & 0,302 & 31,620 & 0,701 & 31,473 & 0,233 \\
\hline 2400 & 31,660 & 31,284 & 1,189 & 31,780 & 0,379 & 31,664 & 0,013 \\
\hline 2640 & 31,770 & 31,332 & 1,378 & 31,820 & 0,157 & 31,727 & 0,135 \\
\hline 2880 & 31,890 & 31,323 & 1,778 & 31,910 & 0,063 & 31,798 & 0,288 \\
\hline 3120 & 31,920 & 31,248 & 2,106 & 31,980 & 0,188 & 31,827 & 0,293 \\
\hline 3360 & 32,000 & 31,237 & 2,385 & 32,030 & 0,094 & 31,818 & 0,568 \\
\hline 3600 & 32,500 & 31,180 & 4,062 & 32,010 & 1,508 & 31,736 & 2,351 \\
\hline 3840 & 32,400 & 31,124 & 3,939 & 32,010 & 1,204 & 31,682 & 2,216 \\
\hline 4080 & 31,890 & 31,107 & 2,456 & 31,990 & 0,314 & 31,627 & 0,823 \\
\hline 4320 & 31,780 & 31,010 & 2,422 & 31,980 & 0,629 & 31,601 & 0,565 \\
\hline 4560 & 31,500 & 30,920 & 1,842 & 31,970 & 1,492 & 31,592 & 0,292 \\
\hline 4800 & 31,200 & 30,872 & 1,051 & 31,890 & 2,212 & 31,576 & 1,207 \\
\hline 5040 & 31,200 & 30,864 & 1,078 & 31,850 & 2,083 & 31,611 & 1,317 \\
\hline 5280 & 31,200 & 30,852 & 1,114 & 31,790 & 1,891 & 31,661 & 1,478 \\
\hline 5520 & 31,200 & 30,822 & 1,213 & 31,750 & 1,763 & 31,552 & 1,127 \\
\hline 5760 & 31,200 & 30,748 & 1,449 & 31,720 & 1,667 & 31,663 & 1,484 \\
\hline 6000 & 31,200 & 30,754 & 1,428 & 31,590 & 1,250 & 31,177 & 0,074 \\
\hline 6240 & 31,190 & 30,710 & 1,539 & 31,510 & 1,026 & 30,877 & 1,004 \\
\hline 6480 & 31,185 & 30,634 & 1,768 & 31,457 & 0,872 & 30,708 & 1,529 \\
\hline 6720 & 31,172 & 30,596 & 1,849 & 31,338 & 0,533 & 30,570 & 1,931 \\
\hline 6960 & 31,114 & 30,555 & 1,798 & 31,229 & 0,370 & 30,479 & 2,040 \\
\hline 7200 & 31,085 & 30,425 & 2,122 & 31,103 & 0,058 & 30,353 & 2,355 \\
\hline \multicolumn{3}{|c|}{ Total average error } & 1,763 & & 1,236 & & 1,387 \\
\hline
\end{tabular}

The total average error between both systems is equal to $1.763 \% ; 1.236 \%$ and $1,387 \%$ approximately, considering the three mesh resolutions. These results validate the simulation of the phenomenon, since the simulated thermal behavior was similar to the temperature values taken in the enclosure. It is also seen in Table 5 that the relative average error for the fine grid was greater than the corresponding error for the medium one, and this is in correspondence with the skewness and orthogonal quality properties, which had worse behavior for the fine grid. Likewise, the Grid Convergence Index (GCI), which provides a consistent way to study the refinement phenomenon of the mesh Roache et al. (1986) and Roache (1998), was calculated. In this case GCI = 0, 67 was obtained. This value is adequate and corresponds to the decrease in grid quality, in terms of skewness and orthogonality, for the fine grid (the assumed time-step guarantees stability of the solution). This suggests an additional future analysis regarding the initial side length of the cubic element, assumed for the coarse grid, which was $30 \mathrm{~cm}$.

Next, in Figures 6 and 7, it is possible to see the polynomial settings for the experimental and simulated data, respectively.

The equations of the temperature-time curves, for experimental and simulated data respectively, are given as example by the following equations:

$$
\begin{array}{cc}
T=-10 t^{3}-6 t^{2}+0.0075 t+22.97 & \text { Eq. } 4 \\
\left(R^{2}=0.9816\right) & \\
T=-10 t^{3}-6 t^{2}+0.008 t+22.081 & \text { Eq. } 5 \\
\left(R^{2}=0.9924\right) &
\end{array}
$$


Figure 6 - Polynomial fit to experimental data

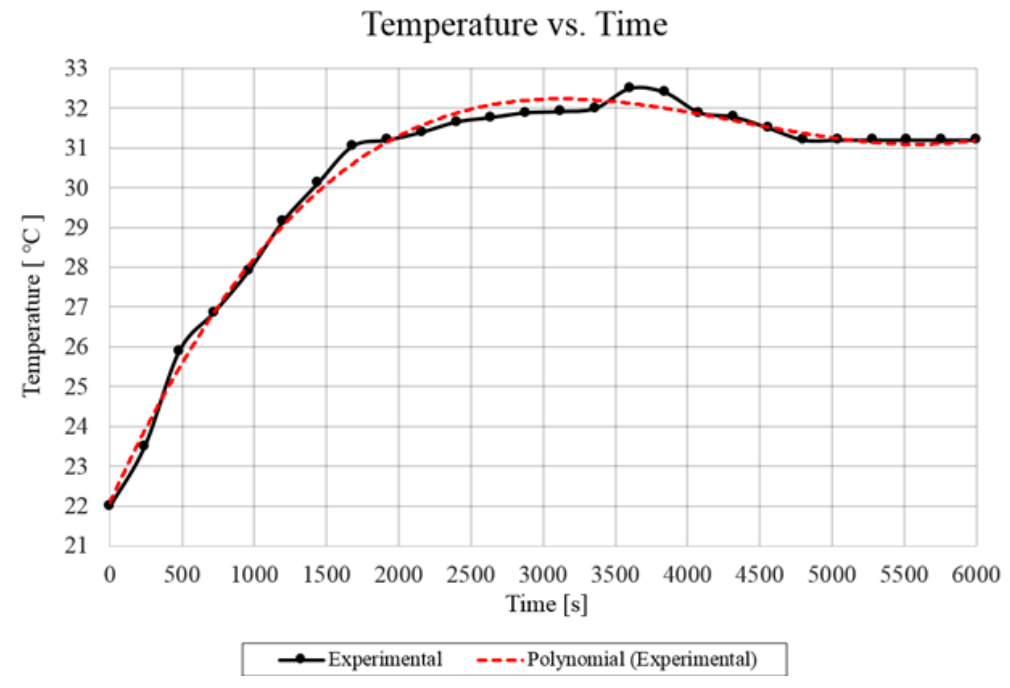

Figure 7 - Polynomial fit to simulated data

Temperature vs. Time

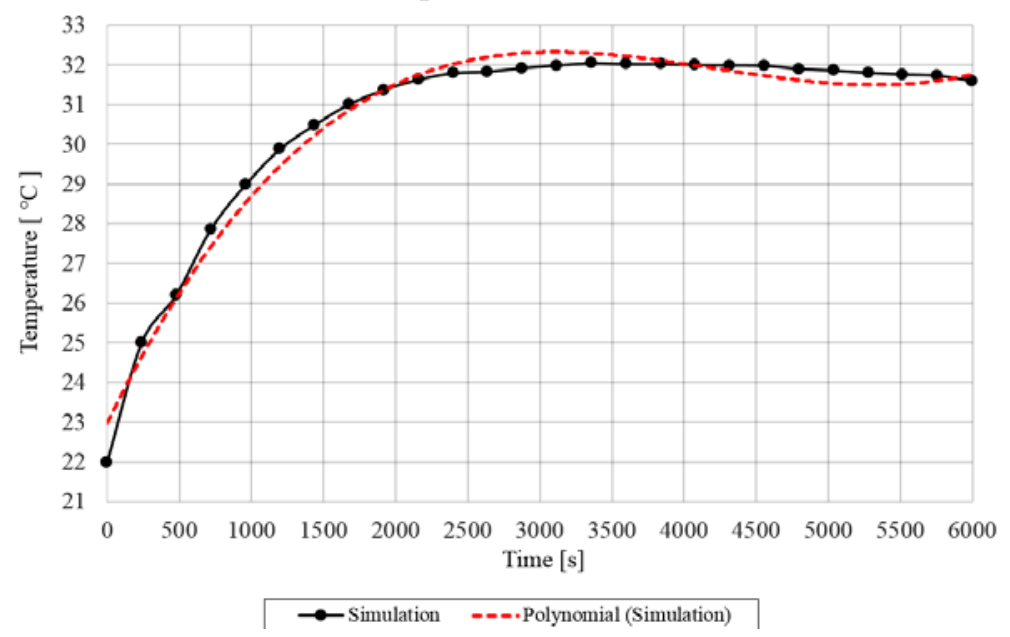

A fictitious plane was considered at a height $1.5 \mathrm{~m}$ above the ground (approximate height at which sated occupants of the cubicle would perceive temperature variations) (see Figure 8).

In Figure 8 it can be noticed that the temperature was higher in the north and east walls of the enclosure, and this is the result of the incidence of solar rays that managed to cross the glasses located in the south and west walls.

In the following sequence of images, the distribution of the temperature on the fictitious plane is observed at 15-minute time intervals (see Table 6).

In addition, equations 4 and 5 show that the time temperature setting, for experimental and simulated results, is good considering that the value of the coefficient of determination is $98.16 \%$ and $99.24 \%$ respectively.

As seen in the previous table, the greatest heat transfer on the reference plane occurred by convection from the areas of incidence of the solar rays on the north and east walls of the cubicle. During the first 60 minutes an increase of 7 degrees centigrade approximately in relation to the initial temperature was noted. From this moment the temperature tended to stabilize inside the enclosure. The reason for such behavior is the change in the position of the sun over time and this affects the north and south walls of the cubicle, decreasing the effect by convection inside the space considered.

In the following figure (see Figure 9) it is possible to view the results of the simulation of the temperature distribution on the limiting surfaces of the enclosure (isometric view) at 15:15 hours. 
Figure 8 - Temperature distribution on a $X Y$ plane at height $Z=1,5 \mathrm{~m}$

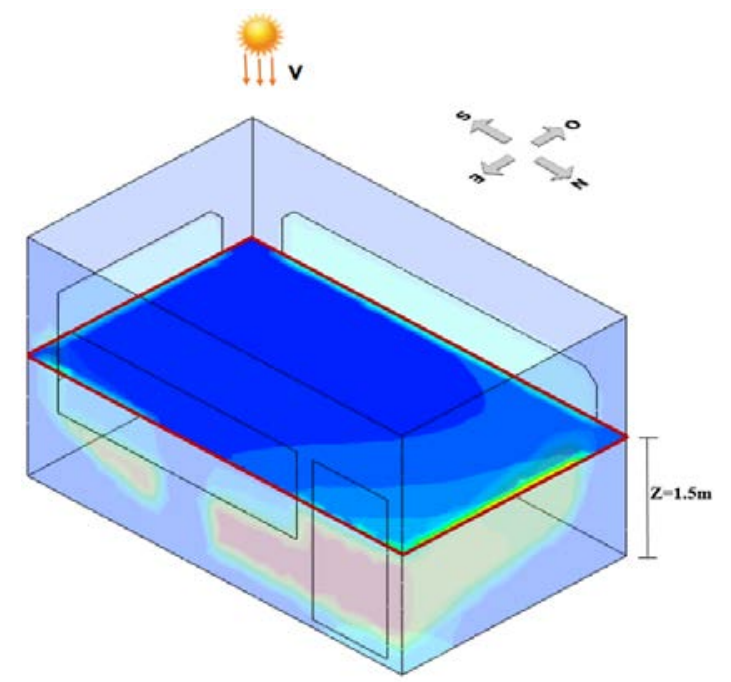

Table 6 -Distribution of the temperature on the fictitious plane, every 15 min

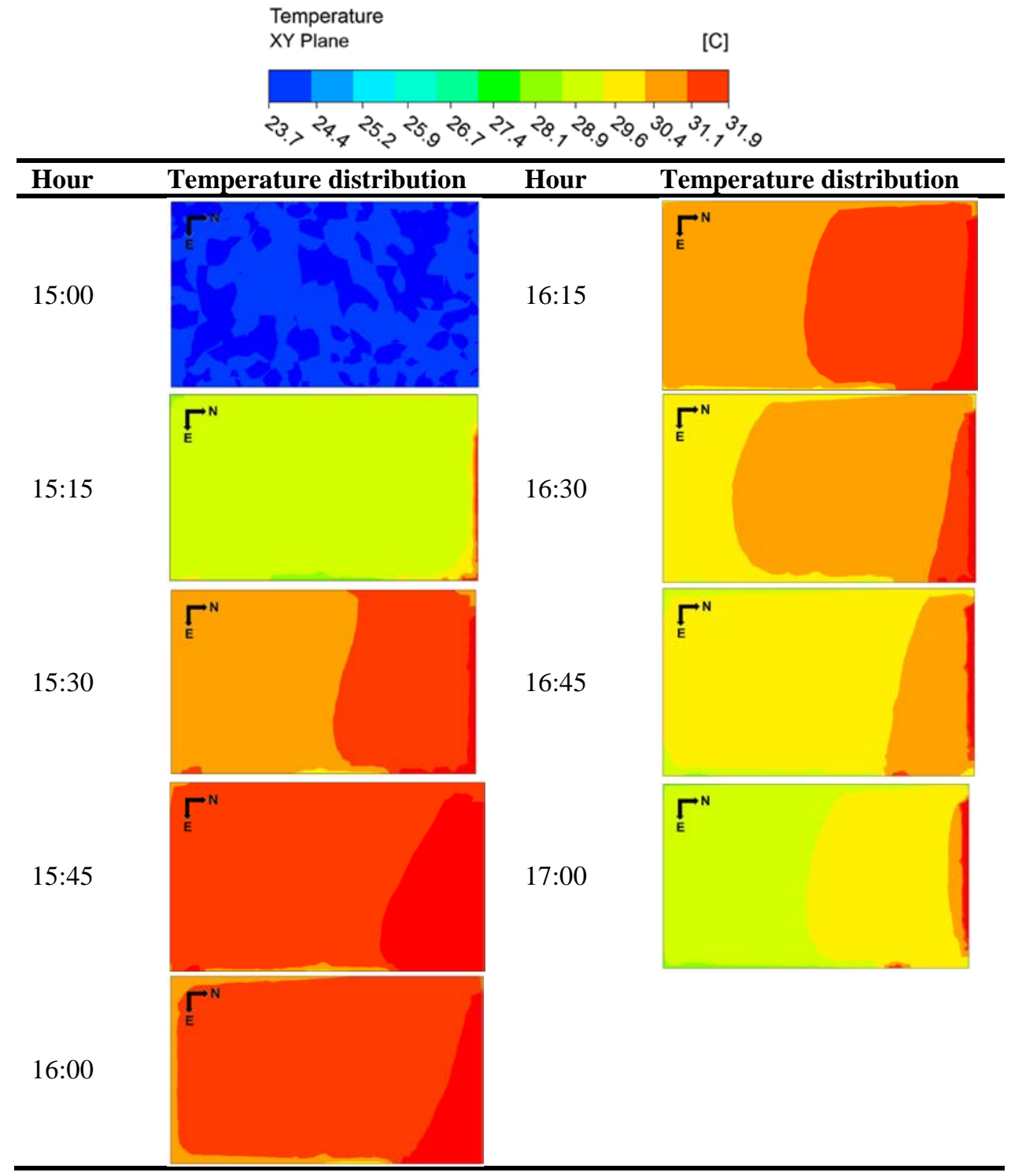


Figure 9 - Distribution of the temperature on the walls of the enclosure ( $t=15: 15$ hours).

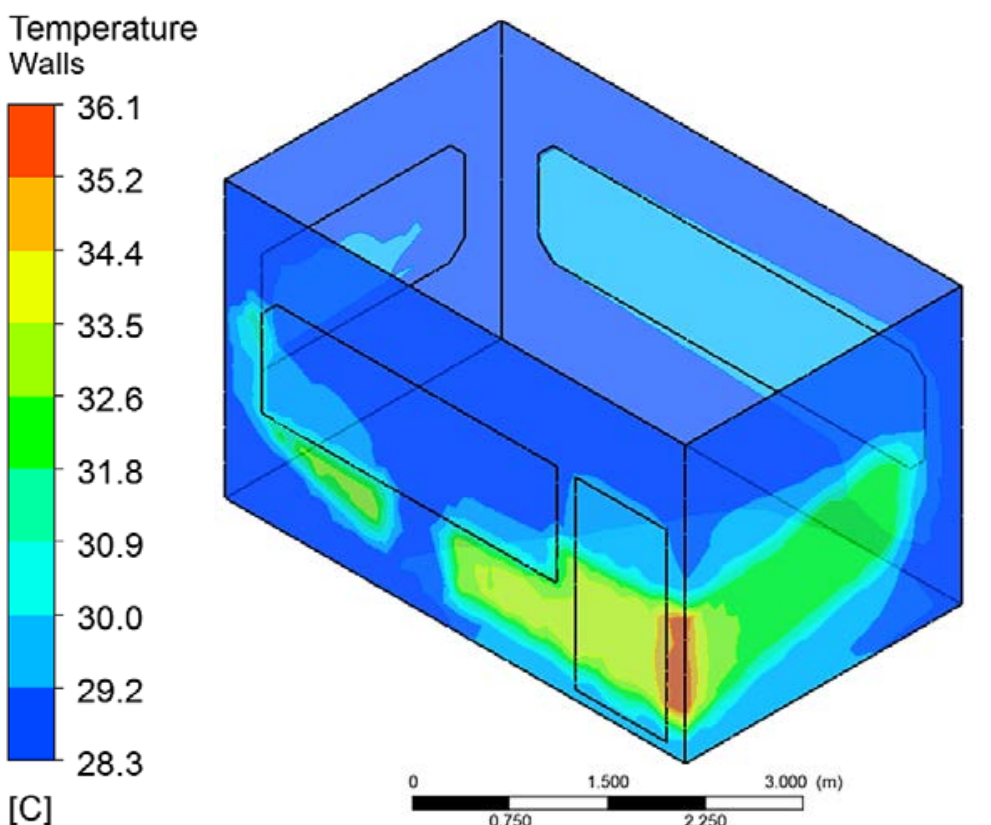

\section{Final considerations}

The curves (temperature vs. time) shown in Figure 5 , refer to the measurement point (PM), and considering the location of this point inside the cubicle, it is clear that the highest incidence on the phenomenon studied was caused by the effect of radiation. Thus, the tolerance of the thermography camera TESTO, used to obtain temperature values on the limiting surfaces of the enclosure (part of the boundary conditions) had an action on the final results, which could be considered negligible. In addition, to measure the temperature in PM, a LM35 sensor was used that had an error tolerance ofup to $\pm 3 / 4{ }^{\circ} \mathrm{C}$. Thus, independently of the deviations of the temperature curve that resulted from the recorded measurements, with respect to the computational ones; the biggest relative error between two measurement points was $4.947 \%$.

The validation of the study performed in FLUENT was based on the dynamic evolution of temperature at a specific pointand on a certain fictional plane in the test-cell, compared to the corresponding experimental data. In this sense, one of the ways of continuity of the present investigation is related to experimentation in order to avoid the reduction of mesh quality (skewness and orthogonality) when it is passed to the mesh with the smallest step. Regardless of this, the sequence of images in Table 6 describes, with acceptable precision, the thermal processes that take place on the fictitious plane, at a significant height in terms of the effect on thermal comfort of people who are using that space, during the critical time interval.
It was perceived that the curves of variation of the temperature with respect to the time, if the same interval of the day is observed (15:00 - 17:00 hours), had a similar behavior to those shown in other investigations, where her factors and combinations of factors were studied Gowreesunker and Tassou (2013), Barbason and Reiter (2014) and GijónRivera et al. (2013). In addition, the Equations 4 and 5 that can describe such behaviors explain the phenomenon in high percentages (98.16\% and 99.24\% for experimental and simulated data respectively). All this guarantees the possibility of applying the developed simulation as a support tool when describing the process of temperature variation in any type of enclosure. This method could be applied as a complement to more complete analysis to determine the air conditioning needs, modifying and adjusting the values that make up the set of input conditions for the software.

To continue this line of research and to improve the obtained results, it would be advisable to use a better measurement instrumentation, with, also, the consideration of possible thermal loads constant in time, inside the cubicle.

\section{References}

AMERICAN SOCIETY OF HEATING, REFRIGERATING AND AIR-CONDITIONING.

Handbook: fundamentals. Pennsylvanya, 2013. 
BARBASON, M.; REITER, S. Coupling Building Energy Simulation and Computational Fluid Dynamics: application to a two-storey house in a temperate climate. Building and Environment, v. 75, p. 30-39, 2014.

CÁRDENAS, D. G. T. Comportamiento Térmico del Espacio Arquitectónico en Construcciones de Adobe. 2015. Tesis (Maestría en Ciencias en Arquitectura y Urbanismo) Instituto Politécnico Nacional, México, 2015.

ÇENGEL, Y. A.; BOLES, M. A. Termodinámica. México: McGraw-Hill, 2003.

ÇENGEL, Y. A.; GHAJAR, A. J. Transferencia de Calor y De masa: fundamentos y aplicaciones. $4^{\text {th. }}$ ed. México: McGraw Hill, 2011.

DECROFET, S. A. DCF (Climatización)

Disponível em:

$<$ http://decofret.com/index.php/nuestrosservicios/climatizacion>. Acesso em: 20 mar. 2019.

ESTEBAN, E. S. et al. Efecto de la Inclinación y de la Separación de las Paredes Activas, en la Transferencia de Calor en Recintos Trapezoidales Calentados Por Debajo. Avances en Energías Renovables y Medio Ambiente, v. 19, p. 08.3708.47, 2015.

ESTEBAN, E. S. et al. Estudio Numérico de la Transferencia de Calor en Recintos Trapezoidales de Baja Razón de Aspecto Calentados por Debajo. Mecánica Computacional. Heat and Mass Transfer (A), v. 34, n. 27, p. 1827-1841, 2016.

FELICES, R. P. et al. Análisis de la Simulación y Monitoreo Real de Un Invernadero en la Implicación Térmica de Un Edificio: un caso práctico. DYNA - Ingeniería e Industria, v. 92, n. 2, p. 209-213, 2017.

FERNÁNDEZ, G. F. Clima y Confortabilidad Humana: aspectos metodológicos. Serie Geográfica, v. 4, p. 109-125, 1994.

GIJÓN-RIVERA, M. et al. Coupling CFD-BES Simulation of a Glazed Office with Different types Of Windows in Mexico City. Building and Environment, v. 68, p. 22-34, 2013.

GONZÁLEZ, C. E. M.; GONZÁLEZ G. S. I. Estudio Experimental Sobre el Comportamiento Térmico de un Nuevo Tipo de Techo-Estanque Para el Enfriamiento Pasivo en Clima Húmedo. Revista da Associação Nacional de Tecnologia do Ambiente Construído, v. 13, n. 4, p. 149-171, 2013.
GOWREESUNKER, B. L.; TASSOU S. A. Effectiveness of CFD Simulation for the Performance Prediction of Phase Change Building Boards in the Thermal Environment Control of Indoor Spaces. Building and Environment, v. 59, p. 612-625, 2013.

INSTITUTO ECUATORIANO DE NORMALIZACIÓN. Eficiencia Energética de Acondicionadores de aire Sin Ductos. Disponível em:

$<$ http://www.normalizacion.gob.ec/wpcontent/uploads/downloads/2013/11/rte_072.pdf>. Acesso em: 20 mar. 2019.

MUÑOZ, V. N. et al. Caracterización del Comportamiento Térmico de Un Edificio Prototipo en Tandil (Buenos Aires). Anales AFA, v. 26, n. 2, p. 78-87, 2015.

MUÑOZ, V. N. et al. Caracterización Térmica de un Edificio del Centro Bonaerense Mediante Mediciones y Modelado Analítico. Avances en Energías Renovables y Medio Ambiente, v. 18, p. 05.19-05.28, 2014.

ORDÓÑEZ, L. E. E.; PÉREZ, S.M. M. Comparación del Desempeño Térmico de Techos Verdes y Techos Blancos Mediante Técnicas IR. Revista Acta Universitaria, v. 25, n. 5, p. 11-19, 2015.

PESÁNTES, M. M. P. Confort térmico en el Área Social de Una Vivienda Unifamiliar en Cuenca, Ecuador. Tesina (Diseñador de Interiores) - Escuela de Diseño, Facultad de Artes, Universidad de Cuenca, 2012.

ROACHE, P. J. et al. Editorial Policy Statement on the Control of Numerical Accuracy. ASME Journal of Fluids Engineering, v. 108, n. 1, p. 2, 1986.

ROACHE, P. J. Fundamentals of Computational Fluid Dynamics. New Mexico: Hermosa Publisher, 1998.

RODRÍGUEZ, M. L. I.; PEÑARANDA, L. Evaluación del Comportamiento Térmico de Edificios Residenciales en Clima Cálido Húmedo. Portafolio 31. Revista Arbitrada de la Facultad de Arquitectura y Diseño de la Universidad del Zulia, v. 1, n. 31, p. 16-31, 2015.

VARINI, C.; Simulaciones: Luciani, S. Calidad de Vida en la Vivienda Social de San Andrés, Colombia, Mediante la Gestión Bioclimática de Flujos de Aire. Revista NODO, v. 9, n. 19, p. 101110, 2015. 


\section{Efrén Vázquez Silva}

Faculdade de Engenharia Mecânica | Universidade Politécnica Salesiana | Calle Vieja, 12-30 e Elia Liut, El Vecino | Cuenca - Ecuador | CP 010105 | Tel.: +(593) 7286-2213 | E-mail: evazquez@ups.edu.ec

\section{Franco David Cajas Muñoz}

Faculdade de Engenharia Mecânica | Universidade Politécnica Salesiana | E-mail: fcajas@est.ups.ecu.ec

\section{Marcelo Xavier Asitimbay Deleg}

Faculdade de Engenharia Mecânica | Universidade Politécnica Salesiana | E-mail: masitimbayd@est.ups.edu.ec

\section{Paúl Bolívar Torres J ara}

Faculdade de Engenharia Mecânica | Universidade Politécnica Salesiana | E-mail: ptorresj@ups.edu.ec

\section{Gabriela Abad Farfán}

Faculdade de Engenharia Mecânica | Universidade Politécnica Salesiana | E-mail: gabadf@ups.edu.ec

Revista Ambiente Construído

Associação Nacional de Tecnologia do Ambiente Construído

Av. Osvaldo Aranha, 99 - 3o andar, Centro

Porto Alegre - RS - Brasil

$$
\text { CEP } 90035-190
$$

Telefone: +55 (51) 3308-4084

Fax: +55 (51) 3308-4054

www. seer. ufrgs. br/ ambienteconstruido

E-mail: ambienteconstruido@ufrgs.br

This is an open-access article distributed under the terms of the Creative Commons Attribution License. 